English books. Noteworthy among the latter are "The Mirror of Alchimy, Composed by the thricefamous and learned Fryer, Roger Bachon", London, 1597; the rare "Secrets Reveal'd : or, An open entrance to the Shut-Palace of the King : Containing The greatest Treasure in Chymistry, Never yet so plainly Discovered", 1669 ; Plat, "The Jewel House of Art and Nature", 1653 ; and many other rare works. Translations into English include Geber, "The Works of Geber, the most famous Arabian prince and philosopher", 1678; Beguin, "Tyrocinium Chymicum", 1669 ; Paracelsus, "The Chymical Transmutation of Metals", 1657 ; Glauber, "The Golden Ass Well Managed", 1670; Gesner, "The newe Iewell of Health", 1576 ; Le Febure, "A compleat Body of Chymistry", 1670; the 1677 and 1686 translations of Lemery, "A Course of Chymistry" and "New Curiosities in Art and Nature", 1711, by the same author.

OF large folios from the Chaston Chapman collection there are good copies of the works of Agricola, Cardanus, Josephus, Lucretius, Manget, Paracelsus, Pettus, Petronius, Sennert, van Helmont, and others. There are some two hundred works by German and Dutch seventeenth-century authors. Becher and Stahl, the two founders of the phlogiston theory, are well represented. There are also certain editions of the strange work "De Secretis", composed by Alexis of Piedmont, a contrite revelation to the world of the secret remedies that might have saved a patient's life. Special attention was also paid by Mr. Chaston Chapman to Black, Boerhaave, Boyle, Newton, and Priestley, and there is an interesting series of old and modern books on brewing and fermentation, commencing with "A Perfite platforme of a Hoppe Garden", 1578. A whole case is devoted to the Royal Society, with the first, second, and fourth editions of Sprat's history of the Society. With the single exception of Lord Brotherton's books, this carefully selected library is the most valuable collection of rare books that the University has ever received.

\section{Bledisloe Medal for Native Agriculture}

IN the recently issued report of the RhodesiaNyasaland Royal Commission (see Nature, May 20, p. 829) stress is laid by members of the Commission in the expression of their individual views regarding certain matters, on the importance of the development of the native for the future of all three territories alike. In this development, agriculture and native husbandry are assigned the foremost place, more especially in the two protectorates, of which the future prosperity can only be based upon agriculture. In the memorandum appended by the chairman, Lord Bledisloe, and Mr. P. A. Cooper, it is said that "Education is a crying need of the African, but its foundation should, in his case, be knowledge of the land and its proper treatment on the one hand and of the basic principles of nutrition and hygiene on the other. These lessons are even more vital to his true welfare than reading and arithmetic, and should take precedence of them." They go on to point out that they are inclined to the view that both land and labour are at present wasted, adding a caution against dogmatic pronouncement that large areas of territory are permanently unsuited to human occupation or economic utilization. In order to encourage the development of the native as agriculturist, Lord Bledisloe has now instituted a silver medal for presentation annually in appropriate numbers to the chiefs of the various tribes of Southern Rhodesia who have done most to induce their tribesmen to adopt improved methods of husbandry. The medal bears on its obverse the figure of a native Afrikander bull with the inscription "Southern Rhodesia Mutungamiri Umtungameli", the Bantu and Sindabele terms for leader or guide. The reverse bears an ear of maize and the inscription "The Bledisloe Medal for the Advancement of Native Husbandry".

\section{Treasure at Delphi}

A DISCOVERY, which would seem to be remarkable even in the annals of Mediterranean archæology for the quantity of objects of gold brought to light, is reported from Delphi, where excavations have been in progress under Prof. Delacotte on behalf of the French School of Archæology at Athens during the past two years. A dispatch from the correspondent of The Times in the issue of May 10 states that in the course of raising and relaying the pavement of the Sacred Way from the eastern side of the Sanctuary in the direction of the Temple of Apollo in a search for inscriptions, a cavity has been found in the centre of the Stoa of the Athenians, in which was a mass of objects, covered with dust and ashes, and including a large number of gold articles. Of these the most important is the gold overlay of a chrys. elephantine statue, of which the ivory has been carbonized. The robe, diadem, ear-rings, bracelets, curls, heads and flowers, which formed the decorations of the robe, and the girdle, all in gold, have been recovered. A bronze statuette holding a receptacle for the burning of aromatic woods, which is complete and of remarkable workmanship, is dated at 500 в.c. In addition, there is a quantity of material in clay, copper and bronze. Expert opinion at present is that the finds show evidence of Oriental influence, possibly originating from the Greek cities of Asia Minor. A further discovery is a second cavity, found in working in a northerly direction from the Sacred Way, which was full of bronze and copper objects, all much encrusted, but otherwise in good preservation. Here also Eastern influence is discerned.

\section{Television and the Provinces}

Mr. C. O. Stanley, chairman of the Television Development Committee of the Radio Manufacturers Association, spoke at Manchester on May 13 outlining the great progress recently made with television. He pointed out that it is necessary to have a universal service for the whole of Great Britain in order to enable manufacturers to develop the export industry. The first step is to extend television to the provinces. While the mentality produced by experimental tele- 